\title{
Impact of Corona Virus on The Life Status of Kurdish People Living in Kurdistan Region of Iraq
}

\author{
Pary M. Azize \\ Nursing Department \\ Sulaimani Technical Institute \\ Sulaimani Polytechnic University \\ Sulaimani, Iraq \\ Pary.azize@spu.edu.iq
}

\author{
Chia H. Sadiq \\ Midwifery Department \\ Sulaimani Technical Institute \\ Sulaimani Polytechnic University \\ Sulaimani, Iraq \\ Chia.sadiq@spu.edu.iq
}

Lavin Luqman Othman

Information Technology Department The British International school of Sulaimani Sulaimani, Iraq

Lavin.luqman97@gmail.com

\begin{tabular}{l} 
Article Info \\
$\begin{array}{l}\text { Special Issue on } \\
\text { Coronavirus (COVID-19) }\end{array}$ \\
DOI: \\
10.24017/covid.6 \\
Article history: \\
Received: 08 May 2020 \\
Accepted: 15 May 2020 \\
\hline
\end{tabular}

Keywords:

Corona virus, Covid 19, Life status, environment, social media, life threatening

\begin{abstract}
The novel corona virus (COVID-19) is currently one of the most common causing concerns in medical community. The aim of this study is to carry out the effect of corona virus on life status among Kurdish people in Kurdistan region. An online form (questionnaire) was used to collect the data among the researchers' social media users, especially Facebook as the main platform. 643 participated in the study and filledout the form; however, 510 forms were accepted in terms of statistical point of view. All statistical computations are enhanced using statistical method (SPSS 21). The data was coded, tabulated, and presented in a descriptive form. The finding shows that the majority of gender respondents were female aged mostly between 15-25 years old, majority were employed, 92.7\%, living in Sulaimani city, which was the highest rate among all locations. 50\% of the participants identified that corona virus was a threatening disease which was the highest. Followed by $22 \%$ who identified the disease as fatal. Social distancing and hand washing were the top choices for self protection against the disease. Family Connection and Relaxation were the two positive aspects of the virus, however, communication with others and safety. Were the two negative aspects of the virus stated by the respondents. $26.1 \%$ of respondents were distracted themselves from stress by connecting with loved
\end{abstract}


ones through social media followed by reading. There is a significant positive statistical correlation between (Corona Virus and life status) which is (0.846) and that the significant value is (0.000). This illustrates that only 71.6\% of factors affect (life status) in (Corona Virus). As way of conclusion, corona virus has had a significant impact on the people's life status.

Copyright () 2020 Kurdistan Journal of Applied Research. All rights reserved.

\section{INTRODUCTION}

The novel Corona Virus (COVID-19) is a new epidemic virus that has raised a big concern among the medical community [1]. This virus is -induced pneumonia, the first report discovered in Wuhan city since 2019 [2]. The number of people living with corona virus across the word is 96,000 cases in 5/3/2020 and 3300 deaths have been reported till the date [3]. Corona virus disease can caused multiple system infections especially respiratory tract infection in humans such as severe acute respiratory syndrome and Middle East respiratory syndrome (MERS) [4]. In addition, cough and fever are the most common symptoms of this virus, some patients have also experienced other symptoms such as diarrhea and liver damage $[5,6]$, it brings more encounters to patients recovery [7,8]. Many people may also be asymptomatic. Usually elderly people and those with chronic disease such as diabetes, cardiovascular diseases, chronic respiratory diseases and cancer are more likely to develop respiratory distress syndrome. Droplets of saliva or contact from an infected person are the most common way of transmission. The incubation period is about 2-14 days. The rate of deaths from this virus is likely to be 2\% -\%3 [9] A study by Joseph et al in 2005 investigated, mental health and quality of life during the SARS pandemic situation among populations in Hong Kong,, it indicated social and family support are associated with positive impact of mental health [10]. In addition, a study conducted among Chines populations through an online survey between January and February 2020 with about 263 participants. This study reported that the COVID-19 was associated with mild stressful impact among local Chinese aged $\geq 18$ in Liaoning Province, mainland China [11]. The occurrence of corona virus over the world can led to enormous public responses; continuously social media has reported across limitations to keep all information taught about the pandemic situation. A pandemic has led to stress, and anxiety, which is the most common reaction to any distressing condition [12]. The most effective ways of protection against the virus is social distance.. Despite all the preventive measures that has been used by people, but still cause stigma. In an online survey that has been carried out in India to assess the knowledge and attitude of people regarding Corona virus, stated that over a fifth of the participants agreed that social distancing, avoiding traveling abroad, frequently using hand sterilizer are protection against the disease, However, stigma and fear are still the dominant factors that stay with them especially because of returning the recovered patients to the society [13]. The aim of this study is to carry out the effect of corona virus on life status among Kurdish people in Kurdistan region

\section{Design of the study}

\section{METHODS AND MATERIALS}

An online survey was conducted, form (questionnaire) was used to collect the data among social media users, especially face book as the main platform.

\section{Data collection}

The form spread around first from the researcher's network especially facebook, then to people who are connected to the researchers facebook accounts all around Kurdistan region. The form was created using Google Forms as the platform. This decision was made because; Google is a very sophisticated and very easy to use platform among online users. The platform 
allows to add questions in variety of styles (multiple choice, short answer, checkbox...etc.). The researchers asked everyone to answer.

\section{Sample and sampling technique}

The form reached 643 subjects. The researchers studied the forms and filtered out 133 forms as they had not filled the form completely. Know the samples are 510 respondents

\section{Questionnaire}

The Questionnaire is classified into two sections, the first section that this research attempted to find some demographic data such as (age, gender, occupation and educational level....). The second section demonstrates the data collected from the first section of the survey, in this section, 12 questions were asked about their life status during that situation of having COVID19. The questionnaire started with the general question about the meaning of Corona virus to them, their level of fear to the disease. Then we started to ask about their social life under the stress of this disease for example: what does Corona Virus give and take away from you, how you protect yourself and how you convince and distract yourself to not become stressed while you are home. Finally, information was seeked about the benefit of staying home and social distance to change the environment for the better and to the future of this Virus.

\section{Statistical analysis}

The answers are automatically turned into useful graphs and figures that are easily extracted and can later on be used as representatives of the data. All statistical computations are enhanced using statistical method (SPSS 21). The data has been coded, tabulated, and presented in a descriptive form. The statistical procedure that was applied to determine the results of the present study included:

1. alpha-cronbach has been used for testing the reliability of the questionnaire.

2. Descriptive statistical data analysis (Demography, descriptive variables as Corona Virus and life status)

3. Inferential data analysis: Pearson bivariate correlation and Simple regression model:

This model was used to determine as: Impact of Corona Virus on the life status

-The significant level of all statistical procedures was determined at (F test), $\mathrm{P}<0.000$.

-There are criteria of the probability level of determining the significance of the test: $\mathrm{P}$-value as:

1. High significant $(\mathrm{P}<0.001)$

2. Significant $(\mathrm{P}<0.05)$

3. Non-significant $(\mathrm{P}>0.05)$

4. Very highly significant $(\mathrm{P}<0.000)$

\section{Reliability of Questionnaire}

\section{RESULTS}

Reliability means accuracy, dependability, stability, and consistency of the research instrument. According to Heale and Twycross, (2015) [14], the recommended appropriate sample size is "approximately 200 individuals (or more) for a research" which implies that a sample size of 200 respondents is an appropriate sample size for the current research.

Table 1: Reliability and Validity

\begin{tabular}{lll}
\hline \multicolumn{1}{c}{ Methods } & Result \\
\hline Alpha Cronbach's & 0.915 & \\
\hline Validity & 0.837 \\
\hline
\end{tabular}

It can be seen in the table (1) that alpha Cronbach was used to get the result of the reliability of the participations. As a result, the value of alpha Cronbach equals to (0.915) and the validity was $(0.837)$, then the result of alpha Cronbach and validity shows the highly reliable of the questionnaire 
Table 2: Demographic data

\begin{tabular}{|c|c|c|}
\hline Variables & Frequency & Percent \% \\
\hline \multicolumn{3}{|l|}{ Gender } \\
\hline Male & 208 & $40.8 \%$ \\
\hline Female & 302 & $59.2 \%$ \\
\hline Total & 510 & $\mathbf{1 0 0 . 0}$ \\
\hline \multicolumn{3}{|l|}{ Age } \\
\hline $15-25$ years old & 211 & $41.37 \%$ \\
\hline $26-35$ years old & 125 & $24.51 \%$ \\
\hline $36-45$ years old & 110 & $21.57 \%$ \\
\hline More than 45 years old & 64 & $12.55 \%$ \\
\hline Total & 510 & 100.0 \\
\hline \multicolumn{3}{|l|}{ Education level } \\
\hline Primary & 15 & $2.9 \%$ \\
\hline Secondary & 38 & $7.5 \%$ \\
\hline Institute & 183 & $35.9 \%$ \\
\hline College & 181 & $35.5 \%$ \\
\hline post graduate & 93 & $18.2 \%$ \\
\hline Total & 510 & 100.0 \\
\hline \multicolumn{3}{|l|}{ Location } \\
\hline Suleimani & 473 & $92.7 \%$ \\
\hline Hawler & 19 & $3.7 \%$ \\
\hline Kirkuk & 5 & $1 \%$ \\
\hline Duhok & 3 & $0.6 \%$ \\
\hline Halabja & 10 & $2 \%$ \\
\hline Total & 510 & 100.0 \\
\hline \multicolumn{3}{|l|}{ Occupation } \\
\hline Student & 152 & $29.8 \%$ \\
\hline Employed & 179 & $35.1 \%$ \\
\hline Teacher & 92 & $18 \%$ \\
\hline Unemployed & 87 & $17.1 \%$ \\
\hline Total & 510 & 100.0 \\
\hline
\end{tabular}

It is clear from the table (2): The majority of gender respondents were female, reaching $59.2 \%$ of the total. This means the rate of females was more than males. The percentage of males was $40.8 \%$.The highest percentage of age was between ( $15-25$ years old) and $24.51 \%$ and $21.57 \%$ were between ( 26 - 35 years old and $36-45$ years old respectively) and only $12.55 \%$ of age was (More than 45 years old).The majority of the educational level was institute, which was $35.9 \%$, while the college, Post graduate and secondary were $(35.5 \%, 18.2 \%$ and $7.5 \%$ respectively) and only $2.9 \%$ was primary. Most of participants, $92.7 \%$ were living in Sulaimani city, which was the highest rate among all locations, 3.7\%, 2\% and 1\% were form hawler ,halabja and kirkuk and the minority of location was in duhok, $0.6 \%$. Occupational status (Employed) from the study sample came in the first rank with a percentage of $35.1 \%$. In the second place were (Students) which was $29.8 \%$, and $18 \%$ of the occupational were Teachers, finally, the lowest rate of occupation, which was Unemployed, $17.1 \%$. 
Table 3: Descriptive some questions

\begin{tabular}{|c|c|c|}
\hline Variables & Frequency & Percent \% \\
\hline \multicolumn{3}{|l|}{ What does corona virus mean to you } \\
\hline It is a threatening disease & 255 & $50 \%$ \\
\hline It is a fatal disease & 112 & $22 \%$ \\
\hline It is a mild disease & 137 & $26.9 \%$ \\
\hline Others & 6 & $1.2 \%$ \\
\hline Total & 510 & 100.0 \\
\hline \multicolumn{3}{|l|}{ How do you protect yourself from the virus? } \\
\hline Washing hands & 224 & $43.9 \%$ \\
\hline Social distancing & 277 & $54.3 \%$ \\
\hline Taking medication and vitamins & 9 & $1.8 \%$ \\
\hline Total & 510 & 100.0 \\
\hline \multicolumn{3}{|l|}{ What did corona virus give to you? } \\
\hline Relaxation & 203 & $39.8 \%$ \\
\hline Family Connection & 224 & $43.9 \%$ \\
\hline Self-care time & 56 & $11 \%$ \\
\hline Others & 27 & $5.3 \%$ \\
\hline Total & 510 & 100.0 \\
\hline \multicolumn{3}{|l|}{ What did corona virus take away from you? } \\
\hline Freedom & 77 & $15.1 \%$ \\
\hline Friendship & 33 & $6.5 \%$ \\
\hline Communication with others & 177 & $34.7 \%$ \\
\hline Economy & 74 & $14.5 \%$ \\
\hline Health & 55 & $10.8 \%$ \\
\hline Safety & 94 & $18.4 \%$ \\
\hline Total & 510 & 100.0 \\
\hline \multicolumn{3}{|c|}{ How do you distract yourself from the stress of the virus? } \\
\hline Reading & 120 & $23.5 \%$ \\
\hline Exercise & 44 & $8.6 \%$ \\
\hline $\begin{array}{l}\text { Connecting with loved ones through social } \\
\text { media }\end{array}$ & 130 & $26.1 \%$ \\
\hline Telephone calls with loved ones & 94 & $18.4 \%$ \\
\hline Sleeping & 34 & $6.7 \%$ \\
\hline Eating & 15 & $2.9 \%$ \\
\hline $\begin{array}{l}\text { Communicating with family members/ house } \\
\text { mates }\end{array}$ & 14 & $2.7 \%$ \\
\hline Others & 56 & $11 \%$ \\
\hline Total & 510 & 100.0 \\
\hline
\end{tabular}

It is clear from the table (3): It can be clear that $50 \%$ of the [articipant6s felt that corona virus was a threatening disease, which was the highest, $26.9 \%$ and $22 \%$ felt mild disease and fatal disease respectively. The majority of the participants chose social distancing as the best way of protecting themselves against the disease. which was $54.3 \%$ of the total and only $1.8 \%$ considered medication and vitamins. According to the study, $43.9 \%$ of corona virus gives family connection and $39.8 \%$ chose relaxation. $34.7 \%$ of participants felt that communication with others was the biggest scarifies that they had to do because of the virus. and $18.4 \%$, 15.1\%. $14.5 \%$ and 10.8 take safety, freedom, economic and health respectively. $23.5 \%$ was 
reading to distract from the stress of virus, and $18.4 \%$ made Telephone calls with loved ones $2.7 \%$ was communicating with family members/ house mate

Table 4: Description of variables

\begin{tabular}{|c|c|c|c|c|c|c|c|}
\hline \multirow[t]{2}{*}{ Questions } & $\begin{array}{l}\text { No } \\
\text { NO }\end{array}$ & $\begin{array}{c}\text { Somehow } \\
\text { NO }\end{array}$ & $\begin{array}{l}\text { Yes } \\
\text { NO }\end{array}$ & \multirow[t]{2}{*}{ Mean } & \multirow[t]{2}{*}{ S.D } & \multirow[t]{2}{*}{ C.V } & \multirow[t]{2}{*}{$\begin{array}{l}\text { Relative } \\
\text { importance }\end{array}$} \\
\hline & $\%$ & $\%$ & $\%$ & & & & \\
\hline \multirow{2}{*}{$\begin{array}{l}\text { Are you afraid of corona } \\
\text { virus? }\end{array}$} & 107 & 274 & 129 & \multirow[t]{2}{*}{2.04} & \multirow[t]{2}{*}{0.67} & \multirow[t]{2}{*}{32.84} & \multirow[t]{2}{*}{68} \\
\hline & 21 & 53.7 & 25.3 & & & & \\
\hline \multirow{2}{*}{$\begin{array}{l}\text { Have you been able to } \\
\text { convince yourself to not } \\
\text { become } \\
\text { Convince by corona } \\
\text { virus. }\end{array}$} & 40 & 174 & 296 & \multirow[t]{2}{*}{2.5} & \multirow[t]{2}{*}{0.64} & \multirow[t]{2}{*}{25.60} & \multirow[t]{2}{*}{83.33} \\
\hline & 7.8 & 34.1 & 58 & & & & \\
\hline \multirow{2}{*}{$\begin{array}{l}\text { Is corona virus your life } \\
\text { threatening virus? }\end{array}$} & 15 & 160 & 335 & \multirow[t]{2}{*}{2.62} & \multirow[t]{2}{*}{0.54} & \multirow[t]{2}{*}{20.61} & \multirow[t]{2}{*}{87.33} \\
\hline & 2.9 & 31.4 & 65.7 & & & & \\
\hline \multirow{2}{*}{$\begin{array}{l}\text { Do you think that social } \\
\text { media adds to the fear of } \\
\text { corona? Does it make } \\
\text { corona seem scary? }\end{array}$} & 50 & 225 & 235 & \multirow[t]{2}{*}{2.36} & \multirow[t]{2}{*}{0.65} & \multirow[t]{2}{*}{27.54} & \multirow[t]{2}{*}{78.67} \\
\hline & 9.8 & 44.1 & 46.1 & & & & \\
\hline \multirow[t]{2}{*}{ Sum } & 212 & 833 & 995 & \multirow[t]{2}{*}{2.38} & \multirow[t]{2}{*}{0.63} & \multirow[t]{2}{*}{26.65} & \multirow[t]{2}{*}{79.33} \\
\hline & 10.39 & 40.83 & 48.77 & & & & \\
\hline
\end{tabular}

The data of Table (4) on repeat distributions (mean, stander deviation, coefficient of variance and Relative importance) indicate explanatory variables that focus on (corona virus). This variable has a mean of 2.38., standard deviation of (0.63) and the relative importance of (79.33\%). The percentage of people who responded with "Yes" to (48.77\%), somehow $(40.83 \%)$, while the proportion of individuals who syayed "No" with the paragraphs have reached the percentage $(10.39 \%)$.

Table 5: Description of variables

\begin{tabular}{|c|c|c|c|c|c|c|c|}
\hline \multirow[t]{3}{*}{ Questions } & No & Somehow & \multirow[t]{2}{*}{ Yes } & \multirow[t]{3}{*}{ Mean } & \multirow[t]{3}{*}{ S.D } & \multirow[t]{3}{*}{ C.V } & \multirow{3}{*}{$\begin{array}{l}\text { Relative } \\
\text { importance }\end{array}$} \\
\hline & NO & NO & & & & & \\
\hline & $\%$ & $\%$ & $\%$ & & & & \\
\hline \multirow{2}{*}{$\begin{array}{l}\text { Do you feel like corona virus } \\
\text { is pushing to stay clean? }\end{array}$} & 14 & 52 & 444 & \multirow[t]{2}{*}{2.84} & \multirow[t]{2}{*}{0.43} & \multirow[t]{2}{*}{15.14} & 94.67 \\
\hline & 2.7 & 10.2 & 87.1 & & & & \\
\hline \multirow{2}{*}{$\begin{array}{l}\text { Do you feel like corona virus } \\
\text { has been able to change the } \\
\text { environment for the better? }\end{array}$} & 11 & 74 & 425 & \multirow[t]{2}{*}{2.81} & \multirow[t]{2}{*}{0.44} & \multirow[t]{2}{*}{15.66} & 93.67 \\
\hline & 2.2 & 14.5 & 83.3 & & & & \\
\hline \multirow{2}{*}{$\begin{array}{l}\text { Do you think that we can end } \\
\text { corona virus by staying clean } \\
\text { and cleaning? }\end{array}$} & 62 & 171 & 277 & \multirow[t]{2}{*}{2.4} & \multirow[t]{2}{*}{0.69} & \multirow[t]{2}{*}{28.75} & \multirow[t]{2}{*}{80.00} \\
\hline & 12.2 & 33.5 & 54.3 & & & & \\
\hline \multirow[t]{2}{*}{ Sum } & 87 & 297 & 1146 & \multirow[t]{2}{*}{2.68} & \multirow[t]{2}{*}{0.52} & \multirow[t]{2}{*}{19.8} & \multirow[t]{2}{*}{89.4} \\
\hline & 5.69 & 19.41 & 74.90 & & & & \\
\hline
\end{tabular}

The data of Table (6) on repeat distributions (mean, stander deviation, coefficient of variance and relative importance) indicate explanatory variables that focus on (life status). This variable has a mean of 2.68. a standard deviation of $(0.52)$ and the relative importance of $(89.4 \%)$. The percentage of people who responded with "Yes" to (74.90\%), somehow 
$(19.41 \%)$, while the proportion of individuals who stated "No" with the paragraphs have reached the percentage $(5.69 \%)$.

Table 6: A relationship between Corona Virus and life status

\begin{tabular}{cc|c|c}
\hline \multirow{2}{*}{ life status } & \multicolumn{3}{c}{ Corona Virus - life status } \\
\hline \multirow{2}{*}{ Corona Virus } & Correlation & Corona Virus & life status \\
\cline { 2 - 4 } & Sig. & 1 & 0.846 \\
\cline { 2 - 4 } & Sample & 510 & 0.000 \\
\cline { 2 - 4 } & Correlation & 0.846 & 510 \\
\cline { 2 - 4 } & Sig. & 0.000 & 1 \\
\cline { 2 - 4 } & Sample & 510 & 510 \\
\hline \hline
\end{tabular}

The level of significance at level 0.05

There is a relationship between the statistical function between the Corona Virus and life status

Ho: There isn't a relationship between Corona Virus and life status

H1: There is a relationship between Corona Virus and life status

It is noted from Table (6) that there is a significant positive statistical correlation between (Corona Virus and life status), which is (0.846) and that the significance value is $(0.000)$ and is less than (0.05). This indicates acceptance of the second hypothesis, because a positive correlation between the (Corona Virus and life status).

Table 7: Regression analysis of a dependent variable (life status) Impact of Corona Virus on the life status

\begin{tabular}{|c|c|c|c|c|c|c|c|c|c|}
\hline \multirow[t]{3}{*}{ Model } & \multicolumn{4}{|c|}{ Coefficients } & \multicolumn{3}{|c|}{ Model Summary } & \multicolumn{2}{|c|}{ ANOVA Table } \\
\hline & $\begin{array}{l}\text { Unstand } \\
\text { Coeffici }\end{array}$ & $\begin{array}{l}\text { ardized } \\
\text { nts }\end{array}$ & T Test & Sig. & $\mathbf{R}$ & $\mathbf{R}^{2}$ & $\underset{\mathbf{R}^{2}}{\text { Adjust }}$ & F Test & Sig \\
\hline & $\mathbf{B}$ & $\begin{array}{l}\text { Std.Erro } \\
\mathbf{r}\end{array}$ & & & & & & & \\
\hline Constant & 0.232 & 0.065 & 3.594 & 0.00 & 0.846 & 0.716 & 0.715 & 1279.67 & 0.00 \\
\hline $\begin{array}{c}\text { Corona } \\
\text { Virus }\end{array}$ & 0.918 & 0.026 & 35.773 & 0.00 & & & & & \\
\hline
\end{tabular}

Ho: There isn't the Impact of Corona Virus on the life status

H1: There is the Impact of Corona Virus on the life status

This table indicates that the regression model predicts the dependent variable significantly well. This indicates the statistical significance of the regression model that was run. Here, the (p-value) was (0.000), which is less than 0.05 , and indicates that, the regression model statistically significantly predicts the outcome variable (it is a good fit for the data).This means that the method is possible to be used to analyze this data and this indicates acceptance of the alternative hypothesis.

The $R^{2}$ value indicates how much of the total variation in the dependent variable (life status), can be explained by the independent variable (Corona Virus). In other words, $\mathrm{R}$ Square for this study is (0.716). In this case, $76.2 \%$ can be explained, which is very large.

In other words, this indicates that $71.6 \%$ of the variance of (life status) has been explored in (Corona Virus), this illustrates that only $71.6 \%$ of factors affect (life status) in (Corona Virus) and the other variables $(28.4 \%)$ are due to random error. 


\section{DISCUSSION}

Corona virus was a life changing disease for everyone and everything around the world. It had its pros and cons. Even though. It was a significant health hazard for humans, but it was able to clean the environment. The virus stopped the life of humans in many countries; however, it was able to restart the life of many other species that used to share the planet with humans. CONVID-19 also had its benefits for humans, it brought families together, stopped many wars and made equality among the different classes in society. However, it did have sever impacts on the mental, financial and the safety status of humans. All of this was the motivation for the conduction of this study. The aim of the research is to find the impact of the virus on the life status of citizens in Kurdistan, Iraq.

Similar to other public health concern for people, corona virus can lead to levels of anxiety and stresses [15].

Regarding the importance of psychological variables, the current study indicated that $\% 25.3$ of participants were frightened from COVID-19. Fear is not the highest impact of corona virus; it has been stated that stress is also another factor when it comes to this pandemic situation. These are inconsistent with the result of a study [16]. In an online survey of 808 U.S. among adults, stated that approximately $56 \%$ of participants were worried or very concerned about the COVID-19 in the U.S. Similarly, a group of researchers asked a number of medical students from the College of Medicine at King Saud University and found that the majority of the subjects fear the disease, interestingly majority $87 \%$ of them were female student [17].

Regarding awareness about COVID -19 pandemic, this study found that most of the participants (\%43.9) were aware of the basic elements of the disease. This study's responders reported that the current use of hand washing indicates the increasing concern of participants toward personal hygiene measure to avoid the virus. This finding is consistent with [18] the study conducted in Indian which stated that $97 \%$ participants were frequently washing their hands to stop the COVID- 19.

In term of social distancing, the majority of the participants in this study reported that more than $(54.3 \%)$ of the participants agreed that social distancing is a significant impact to avoid the disease. This finding is consistent with the study which indicated that awareness about COVID-19 is reflected in their attitude and behaviors considerably as most of the Chines participants (about 98\%) agreed with social distancing [18].

This study represents that, most of the participants stated that corona virus has the highest (\% 83.3) impact to change the environment for the best. This result is supported by a study form China. The study reported that the corona virus can prevent the environment form pollution and significantly contributes in reduction to global carbon emission [19].

In this context, social media may be one of the most important impacts on mental health. This study stated that social media was responsible for spreading fear of COVID-19 among participants, which is about (\% 46.1) of all individuals. This finding is consistent with [20], the MERS outbreak period, which indicated that social media can influence largely express negative words like fear and anxiety with respect to the infectious disease. In contract, as in the locked down situation, social media is the main source to gain information about COVID19 in about half of the population [21]. In a two similar studies on MERS was consisted results that social media is a main source of information among health care professionals $[22$, 23].

\section{CONCLUSION}

As way of conclusion, this study showed that corona virus has had a significant impact on the life status of citizens in Kurdistan, Iraq. The results showed that the majority of the subjects were suffering from mental instability as the cause of the epidemic. Social distancing was chosen as the best way to protect themselves and their families from the contagious virus. CONVID-19 changed the world in many ways. Despite its many negative impacts, it will be able to have long term benefits for humans, the planet and the different species. 


\section{REFERENCE}

[1] Z Na, Z Dingyu, W Wenling, Li Xingwan , Bo Yang, S Jingdong et al. A novel corona virus from patients with pneumonia in China, The New England Journal of Medicine. 382, pp.727-33. 2019

[2] Li Quan, G Xuhua, W Peng, W Xiaoye, Z Lei T Yeqing et al. Early Transmission Dynamics in Wuhan, China, of Novel Coronavirus-Infected Pneumonia. The New England Journal of Medicine, 382, pp.1199-1207 2020.

[3] Coronavirus Outbreak. Available at: https://www.worldometers.info/coronavirus/. Accessed 23 Feb 2020.

[4] N, Chen, M Zhou, X Dong, J Qu, F Gong, Y Han et al. Epidemiological and clinical5 characteristics of 99 cases of 2019 novel coronavirus pneumonia in Wuhan, China: a descriptive study. Lancet.;395 (10223), pp.507-513 2020.

[5] C Xiaoqiang, Hu Longfei, Z Yan, H Weiyu, L Zhou, $\mathrm{K}$ Aiwu et al., Specific ACE2 Expression in Cholangiocytes May Cause Liver Damage After 2019-nCoV Infection. bioRxiv,. 02.03.931766, 2020.

[6] N, Chen, M Zhou, X Dong, J Qu, F Gong, Y Han et al. Epidemiological and clinical5 characteristics of 99 cases of 2019 novel corona virus pneumonia in Wuhan, China: a descriptive study. Lancet.;395 (10223), pp.507-513 2020.

[7] L, Michae, M Andrea. and M Vincient, Functional assessment of cell entry and receptor usage for lineage B $\beta$ corona viruses, including 2019-nCoV. Nature Microbiology 5, pp. 562-569. 2020. [8] Z Peng, L Xing- XYang,, W Guang, H Ben, Z Lei, et al., Discovery of a novel corona virus associated with the recent pneumonia outbreak in humans and its potential bat origin. Nature, 01.22.914952, 2020

[9] S Tanu. A Review of Corona virus Disease-2019 (COVID-19). The Indian Journal of Pediatrics, 87, pp. 281286. 2020.

[10] T. F Joseph., X Lau, K W Yun . Positive mental health-related impacts of the SARS epidemic on the general public in hong kong and their associations with other negative impacts. Journal of Infection 53, pp 114-124. 2005.

[11] Z Yinfiei and F M Zheng, Impact of the COVID-19 Pandemic on Mental Health and Quality of Life among Local Residents in Liaoning Province, China: A Cross-Sectional Study, International Journal of Environment Research and Public Health 2020, pp, 17(7), pp 2381.

[12] R Deblina, T Sarvodaya, K K Sujita, S Nivedita, VK Sudhir and K Vikas. Study of knowledge, attitude, anxiety \& perceived mental healthcare need in Indian population during COVID-19 pandemic. Asian Journal of Psychiatry. 51: 102083, 2020.

[13] R Deblena, T Sarvodaya, KK Sujita, S Nivedita, VK Sudhir, K Vikas. Study of knowledge, attitude, anxiety \& perceived mental healthcare need in Indian population during COVID-19 pandemic. Asian Journal of Psychiatry. 5, 102083, 2020.

[14] H Roberta, T Alison, Validity and reliability in quantitative studies, Evidence Based Nursing Journal, 18.\{3). Pp. 66-67. 2015.

[15] M Nicola. The emotional impact of COVID-19: From medical staff to common people. Brain, behavior, and immunity. pp 138159, 2020.

[16] A, Allison. Poll: Most Americans say U.S. "doing enough" to prevent corona virus spread, The Coronavirus Crisis, 2020. https://www.npr.org/sections/healthshots/2020/02/04/802387025/poll-mostamericans-say-u-sdoing-enough-to-preventcoronavirus-spread.

[17] A R Abdulkarim , HT Mohammad, AA Ayman, , HM Gamal Al-Z Fahad, Al-S Sarah, et al., . Middle East Respiratory Syndrome-Corona Virus - (MERS-CoV) associated stress among medical students at a university teaching hospital in Saudi Arabia. Journal of Infection and Public Health. 13\{5), pp. 687-691. 2020.

[18] R Deblina, T Sarvodaya, K K, Sujitta, S Nivedita, KV, Sudhir and K Vitas. Study of knowledge, attitude, anxiety \& perceived mental healthcare need in Indian population during COVID-19 pandemic. Asian Journal of Psychiatry. 51, pp. 102083. 2020.

[19] W Qiang, Su Min A preliminary assessment of the impact of COVID-19 on environment - A case study of China. Science of the Total Environment. 728, pp.138915. 2020.

[20] H C Doo, Y Woohyun, YN Ghee, P Keeho The impact of social media on risk perceptions during the MERS outbreak in South Korea. Computers in Human Behavior;72: pp. 422-431. 2017.

[21] K Reema, Al-A Sayer, M Suhaib , S Ola , H Sahar and K Yousef . Media's effect on shaping knowledge, awareness risk perceptions and communication practices of pandemic COVID-19 among pharmacists. Research in Social and Administration Pharmacy. O4-027, 2020

[22] GM Leung, T-H, Lam, SY Ho, BH Chan, IQ Wang and AJ Hedley. The impact of community psychological responses on outbreak control for severe acute respiratory syndrome in Hong Kong. Journal of Epidemiology and Community Health. 57(11), pp. 857-63. 2003.

[23] Di Gaberilla,, A Rossella, A. Luciania M Paolo and AF Italo. A survey of knowledge, attitudes and practices towards avian influenza in an adult population of Italy. BMC Infectious Disease. 8(36), 2008 . 